\title{
Clinicopathological analysis of acral melanoma in a single center: a study of 45 cases
}

\author{
(D) Bruno de Castro e Souza' \\ (iD) Diego Henrique Morais Silva² \\ (iD) Denis Miyashiro ${ }^{3}$ \\ (iD) Priscila Kakizaki4 \\ Neusa Yuriko Sakai Valente
}

\begin{abstract}
1. Médico Dermatologista - Departamento de Dermatologia do Hospital das Clínicas da Universidade de São Paulo, São Paulo, SP, Brasil. 2. Médico Residente - Médico Residente do Departamento de Dermatologia do Hospital do Servidor Público Estadual de São Paulo, São Paulo, SP, Brasil. 3. Médico Dermatologista Preceptor da Dermatologia do Hospital das Clínicas da Universidade de São Paulo Departamento de Dermatologia do Hospital das Clínicas da Universidade de São Paulo, São Paulo, SP, Brasil. 4. Médica Dermatologia Preceptora do Hospital do Servidor Público Estadual de São Paulo Departamento de Dermatologia do Hospital do Servidor Público Estadual de São Paulo, São Paulo, SP, Brasil. 5. Doutora em Dermatologia - Departamento de Dermatologia no Hospital do Servidor Público Estadual de São Paulo, São Paulo, SP, Brasil.
\end{abstract}

\section{SUMMARY}

OBJECTIVE: The relationship between the clinicopathological and sociodemographics characteristics of acral melanomas diagnosed at the Hospital do Servidor Público Estadual de São Paulo was analyzed and traced between 1997 and 2016.

METHODS: An observational, descriptive, and retrospective study of patients diagnosed with acral melanoma was performed at Hospital do Servidor Público Estadual de São Paulo. Sociodemographic and clinicopathological characteristics were collected and analyzed.

RESULTS: Forty-five patients with acral melanomas were found during the evaluation period. Thirty-one were females, and 14 were males (68.89\% and $37.3 \%$, respectively). Most of the cases were invasive (88.37\%), and the predominant histological subtype was the acral lentiginous (91.11\%). The plantar region was the most prevalent (64.44\%). The median Breslow index was $3 \mathrm{~mm}$, and there was a tendency towards greater severity in male patients.

CONCLUSIONS: Acral site melanomas are detected diagnosed when they reach more advanced stages, which leads to a worse prognosis for patients. Late detection assumes even greater importance in highly mixed and black populations, such as the Brazilian population. KEYWORDS: Melanoma/epidemiology. Melanoma/pathology. Skin neoplasms.

\section{INTRODUCTION}

Despite the tremendous therapeutic advance of oncology, melanoma remains a neoplasm with a high mortality rate. ${ }^{1,2} \mathrm{~A}$ progressive increase in the incidence of this pathology has been reported. Despite efforts and campaigns, many cases are still diagnosed when they are already in the invasive phase. ${ }^{3}$ From a clinical and pathological point of view, primary cutaneous melanoma is divided into extensive superficial, nodular, malignant lentigo melanoma and acral lentiginous.

Such subtypes, in addition to histopathological differences, present different risk factors and clinical and demographic characteristics. With the advancement in molecular and genetic techniques, it was noticed that they also have divergences in oncogenic mutations. ${ }^{4,5}$ This finding has led to therapeutic 
implications with the development of targeted therapies and immunotherapies. ${ }^{6-8}$

Any skin surface can be a primary melanoma site. The most frequent site of involvement depends directly on the skin color of the affected individual. In Caucasians, the head, neck, trunk, and limbs are the preferred places, whereas in Asians and blacks, melanomas more frequently affect acral locations (mainly hands and feet). ${ }^{9-12}$ All histological subtypes may have an acral origin (except for malignant lentigo as the lentigo occurs in photodamaged skin) with the acral lentiginous subtype being the most common in such locations.

Brasil is a country with a highly miscegenated population with the majority of the population composed of blacks, so it is a territory with a large number of acral cutaneous melanomas. ${ }^{13}$ However, despite this diverse population, few studies have specifically focused on these cases. Thus, cases of acral melanoma in a single center in the city of São Paulo are described.

\section{METHODS}

An observational, descriptive, retrospective study of patients diagnosed with melanoma in an acral site (feet and hands) was carried out between 1997 and 2016 at Hospital do Servidor Público Estadual de São Paulo.

Sociodemographic and clinicopathological characteristics, including sex, age, anatomical site, histological type, tumor thickness, ulceration, mitotic index, and 5-year survival, were collected and analyzed.

Statistical analysis was performed with STATA version 13 (STATA Corp., Texas, United States). The Shapiro-Wilk normality test showed that all quantitative data were non-parametric. Thus, the median and interquartile range (IQR) and the Wilcoxon ranksum test were used to describe the data and associations. Qualitative data are shown as frequency and percentages, and analyses were performed using the chi-square or Fisher's exact test. Statistical significance was considered to be $\mathrm{P} \leq 0.05$.

\section{RESULTS}

Of the 386 cases of primary cutaneous melanoma, 52 were located in the acral region (hands and feet). According to the classification of cutaneous tumors of the World Health Organization (WHO), acral cutaneous melanoma is located in non-exposed areas such as hands and feet (palmar, plantar, and nail apparatus). ${ }^{14}$
Thus, excluding patients with the ankle ${ }^{4}$ and dorsum of the foot $^{3}$ melanomas, a statistical analysis was performed with 45 patients.

Tumor characteristics and the demographic variables of each patient included in this study are shown in Table 1. Among 45 patients included in the analysis, 31 were female $(68.89 \%)$ and 14 were males (31.11\%). Most melanomas were invasive (38 patients, 88.37\%), and only 5 (11.63\%) of the cases were melanoma in situ. The histological subtype acral lentiginous melanoma was found in 41 cases (91.11\%). Four patients (8.89\%) did not have the specified histological type (melanoma, NOS). The median age at diagnosis was 69 years (IQR: 61-77 years).

\section{TABLE 1. PATIENT CHARACTERISTICS}

\begin{tabular}{|c|c|}
\hline \multicolumn{2}{|l|}{ Gender [n (\%)] } \\
\hline Female & $31(68.89 \%)$ \\
\hline Male & $14(31.11 \%)$ \\
\hline \multicolumn{2}{|l|}{ Age (years) } \\
\hline Mean (SD) & $68.71(11.13)$ \\
\hline Median (IQR) & $69(77-61)$ \\
\hline \multicolumn{2}{|l|}{ Anatomical Site [n (\%)] } \\
\hline Plantar Region & $29(64.44 \%)$ \\
\hline Subungual (Pododactyl) & $8(18.00 \%)$ \\
\hline Subungual (Quirodactyl) & $6(13.33 \%)$ \\
\hline Palmar Region & $1(2.22 \%)$ \\
\hline Unspecified & $1(2.22 \%)$ \\
\hline \multicolumn{2}{|l|}{ Histological Type [n (\%)] } \\
\hline Acrolentiginous & $41(91.11 \%)$ \\
\hline Unspecified & $4(8.89 \%)$ \\
\hline \multicolumn{2}{|l|}{ Breslow (mm) } \\
\hline Average & 5.09 \\
\hline Median (IQR) & $3(5.5-1)$ \\
\hline \multicolumn{2}{|l|}{ Invasion $[\mathrm{n}(\%)]$} \\
\hline Invasive & $38(88.37 \%)$ \\
\hline In situ & $5(11.63 \%)$ \\
\hline \multicolumn{2}{|l|}{ Ulceration $[\mathrm{n}(\%)]$} \\
\hline Yes & $19(42.22 \%)$ \\
\hline No & $26(57.78 \%)$ \\
\hline \multicolumn{2}{|c|}{ Mitosis greater than $1[\mathrm{n}(\%)]$} \\
\hline Yes & $23(52.27 \%)$ \\
\hline No & $21(47.73 \%)$ \\
\hline \multicolumn{2}{|l|}{ Clark's index $[\mathrm{n}(\%)]$} \\
\hline I & $4(8.89 \%)$ \\
\hline II & $5(11.11 \%)$ \\
\hline III & $7(15.56 \%)$ \\
\hline IV & $26(51.11 \%)$ \\
\hline V & $6(13.33 \%)$ \\
\hline \multicolumn{2}{|l|}{ 5-year survival [n (\%)] } \\
\hline Yes & $23(67.65 \%)$ \\
\hline No & $11(32.35 \%)$ \\
\hline
\end{tabular}

$\mathrm{SD}=$ Standard Deviation; $I \mathrm{QR}=$ Interval between $25^{\text {th }}$ and $75^{\text {th }}$ quartiles 
In terms of location, the lesions were from the plantar region in 29 cases (64.44\%), subungual in 14 patients (of these, eight located in toes and six in fingers), and only one case in the palmar region (2.22\%). The median Breslow index was $3 \mathrm{~mm}$.

As for histological characteristics, 19 patients had tumors with ulceration (42.22\%), and 23 (52.27\%) had more than one mitosis per field. Most patients (23, 51.11\%) had melanomas with Clark IV.

Table 2 shows histological characteristic distribution of melanomas according to patient sex. Mean age at diagnosis was similar in both groups, 68 years for women, and 69.5 years for men. Tumors were located on the feet in 26 cases (83.87\%) in women and 11 (78.57\%) among men. Similar behavior between the sexes was also found regarding the histological subtype with the majority of patients presenting acrolentiginous melanoma (28 patients, $90.32 \%$ of women and 13 patients, $92.86 \%$ of men) and regarding the presence of invasion. No statistical difference regarding fiveyear mortality $(50.00 \% \times 22.73 \%$; $p=0.104)$, ulcerations $(57.14 \%$ x $35.48 \%$; $=0.173)$, and mitosis $(71.43 \%$ $x$ 43.3\%; $p=0.082$ ) between the sexes were noted.

TABLE 2. CHARACTERISTICS OF TUMORS ACCORDING TO SEX.

\begin{tabular}{|c|c|c|c|}
\hline \multirow[t]{2}{*}{ Variables } & \multicolumn{2}{|l|}{ Gender } & \multirow[t]{2}{*}{ value $P$} \\
\hline & Female & Male & \\
\hline \multicolumn{3}{|l|}{ Anatomical Site } & 0.667 \\
\hline Hand & $16.13 \%$ & $21.43 \%$ & \\
\hline Foot & $83.87 \%$ & $78.57 \%$ & \\
\hline \multicolumn{3}{|c|}{ Histological Subtype } & 0.782 \\
\hline Acrolentiginous & $90.32 \%$ & $92.86 \%$ & \\
\hline Not specified & $9.68 \%$ & $7.14 \%$ & \\
\hline \multicolumn{3}{|l|}{ Invasion } & 0.524 \\
\hline In situ & $13.79 \%$ & $7.14 \%$ & \\
\hline Invasive & $86.21 \%$ & $92.86 \%$ & \\
\hline \multicolumn{3}{|l|}{ Ulceration } & 0.173 \\
\hline Yes & $35.48 \%$ & $57.14 \%$ & \\
\hline No & $64.52 \%$ & $42.86 \%$ & \\
\hline \multicolumn{3}{|l|}{ Mitosis } & 0.082 \\
\hline Yes & $43.33 \%$ & $57.14 \%$ & \\
\hline No & $56.67 \%$ & $42.86 \%$ & \\
\hline \multicolumn{3}{|l|}{ 5-year survival } & 0.104 \\
\hline Yes & $77.27 \%$ & $50.00 \%$ & \\
\hline No & $22.73 \%$ & $50.00 \%$ & \\
\hline \multicolumn{3}{|l|}{ Breslow } & 0.459 \\
\hline Average & 4.12 & 6.97 & \\
\hline Median (IQR) & $3(5-1)$ & $3(6-1.3)$ & \\
\hline \multicolumn{3}{|l|}{ Age (years) } & 0.854 \\
\hline Mean (SD) & $69.06(11.55)$ & $68.00(10.54)$ & \\
\hline Median (IQR) & $68.00(78-60)$ & $69.50(74-61)$ & \\
\hline
\end{tabular}

When analyzing the anatomical sites and the different characteristics of the tumors (figure 1), similar behavior was observed in terms of invasion since most tumors were invasive, both in the subgroup of tumors located in the feet (91.67\%) and in the hands (71.43\%). The 5-year survival also showed no statistical difference between the two groups (hands and feet). No statistical difference in thickness between the tumors located on the hands (mean and median $6 \mathrm{~mm}$ ) in relation to those present on the feet (mean and median 4.96 and $3 \mathrm{~mm}$, respectively).

FIGURE 1. CHARACTERISTICS OF MELANOMAS IN TERMS OF LOCATION (FEET X HANDS).

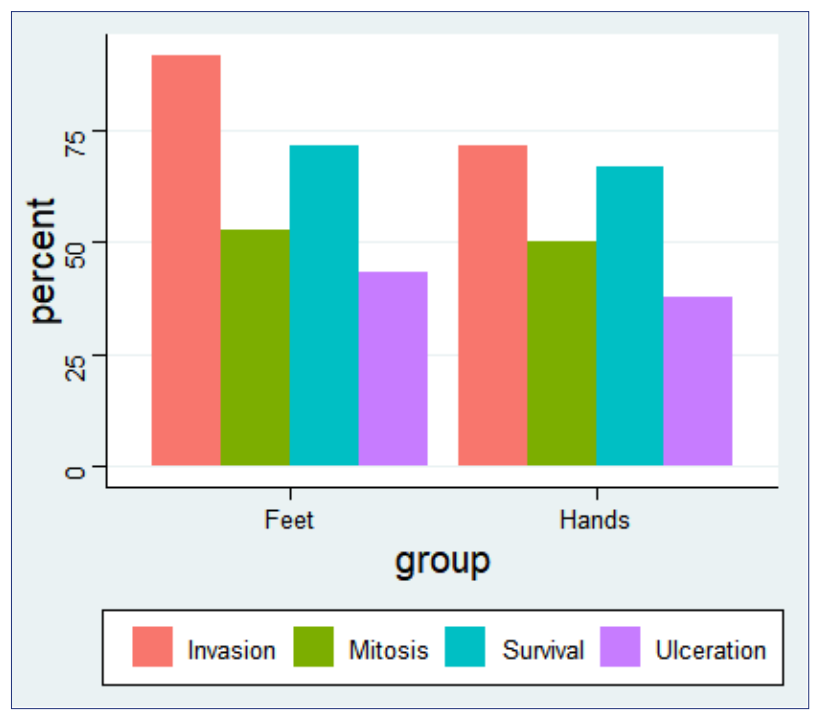

\section{DISCUSSION}

We present a series of 45 cases of acral melanoma diagnosed between 1997 and 2016 at the Hospital do Servidor Público Estadual de São Paulo (HSPE). In this study, we correlated the demographic characteristics of each patient with the clinical and histopathological findings.

The acral location corresponds to body extremities, such as the hands and feet. Such anatomical sites can be the site of melanomas of different histological types, the most common being the so-called acral lentiginous melanoma. ${ }^{11}$ These names lead to errors since many dermatologists confuse the anatomical location with the histological subtype, a finidng that is reflected in scientific studies. In the present study, we included all primary cutaneous melanomas that appeared in the glabrous skin of the hands and feet in addition to melanomas originating from the nail apparatus according to the WHO's definition of acral melanoma. Despite 
being located in an acral site, the melanomas arising in the dorsum of the foot and hands are not included in WHO's definition of acral melanoma.

In accordance with already published studies, most patients had tumors on the soles of their feet, whose involvement was 3 to 10 times more common than that found on the hands. ${ }^{13-16}$ The lentiginous acral histological type was found in $91.11 \%$ of the cases and was the predominant one in both sexes in this study in agreement with the international and national literature.

Only one case of melanoma was diagnosed in the palmar region during this study period, confirming the rarity of this involvement as described in other studies. ${ }^{13,15}$ Besides, the tumors located in the hands showed a larger thickness at diagnosis than the observed in melanomas diagnosed in the feet. However, we did not demonstrate statistical significance for this data.

Due to this preference for the plantar region, it has been postulated that lentiginous acral melanoma has different behavior and risk factors in relation to other histological subtypes, including repetitive trauma as a predisposing factor ${ }^{13,16,18}$ since different from other histological types, ultraviolet radiation seems to have little influence as a risk factor for lentiginous acral melanoma. ${ }^{17,18}$

Subungual melanoma accounted for an important percentage of acral tumors as it was the second most common location. Ultraviolet radiation also seems to have little influence on the development of these neoplasms. A compact layer of keratin works as a protective factor for matrix melanocytes, the source of this type of melanoma. ${ }^{18}$ In our sample, we found a higher amount of melanomas in the toenail apparatus ${ }^{8}$ in the fingers. ${ }^{6}$ In the literature, nail melanoma is more frequent in the fingers; however when the melanoma returns, it occurs more in the plantar region. This finding suggests that the factors involved in the oncogenesis of nail melanomas and those located on the plantar/palmar face may be different. ${ }^{19,20}$

When compared to the other melanoma subtypes, especially in photoexposed areas, lentiginous acral presents a lower incidence of BRAF activating mutations, accounting for only $17 \%$ of cases. ${ }^{19-28}$

Most tumors are already diagnosed when they are invasive in the vertical growth phase. The median Breslow index of $3 \mathrm{~mm}$ and most of the cases being Clark's level IV corroborate this observation. The average thickness of the tumors at diagnosis was similar to that found in the national study and is classically associated with poor prognosis. ${ }^{13-18}$

We also demonstrated that most tumors had mitoses at diagnosis, and almost half of the tumors contained ulcerations. These are significant findings since both are markers of worse prognosis, indicating a higher risk of metastasis. ${ }^{19,20}$

Thus, these data support the fact that melanoma in the acral region, regardless of the histological subtype, is usually diagnosed late in relation to melanomas in other locations. A complete physical examination, including inspection of the palmar and plantar regions and the education of patients can reduce these indicators. ${ }^{17,21}$

The sex ratio found in this series (1 man for every 1.36 women) is similar to that previously reported. ${ }^{13-15}$ Nunes et al. (2018) demonstrated a mean age at diagnosis similar to that shown in this study (68.71 years). ${ }^{13}$

The data collected in our study show a trend toward greater severity in male patients since they have a higher number of mitoses, thickness, ulcerations, and, consequently, a lower five year survival rate. Sex has been recognized in other studies as an independent prognostic factor for melanoma although the reasons for longer prolonged survival in women remain unclear. ${ }^{13,22}$ Although the diagnosis is made earlier in women, who usually practice better self-care, this finding does not seem to be sufficient to explain the difference in prognosis between the sexes. Some theories about the difference between genders suggest a role for oxidative stress and estrogen as a protective factor in women at menarche..$^{\mathbf{2 0}}$ 23,24.

The challenge of early acral melanoma diagnosis, especially the lentiginous subtype, has prompted further studies to better understand the pathogenesis of this nosological entity. A promising área is the development of target therapies since new studies have elucidated the molecular and genetic aspects of acral lentiginous melanoma. ${ }^{18,23}$ It is postulated that kinase-dependent cyclin (cyclin D1) acts as an oncogene in this melanoma subtype as identified early by the in situ hybridization technique (FISH). ${ }^{18}$ Also, acral lentiginous melanoma presents a higher frequency of mutations in tyrosine kinase receptors (KIT), which has even been associated with the advanced Clark level. ${ }^{17,25}$ These findings are relevant since therapies aimed at these KIT mutations are already available for other neoplasms. ${ }^{25}$ 


\section{CONCLUSION}

Melanomas that develop in acral sites have a very high average thickness at diagnosis, which reinforces the importance of redoubling our efforts to establish public policies for the earlier recognition of this condition. Gender also seems to influence the prognosis of these patients, and larger studies need to be conducted for better definition.

\section{Author's Contribution}

All authors have contributed equal to work.

\section{RESUMO}

OBJETIVO: Analisar e traçar uma relação entre as características clinicopatológicas e sociodemográficas dos melanomas acrais diagnosticados no Hospital do Servidor Público Estadual de São Paulo.

MÉTODOS: Fez-se um estudo observacional, descritivo e retrospectivo de pacientes diagnosticados com melanoma em sítio acral entre 1997 e 2016 no Hospital do Servidor Público Estadual de São Paulo. Características sociodemográficas e clinicopatológicas foram coletadas e analisadas.

RESULTADOS: Foram encontrados 45 pacientes com melanoma acral no período avaliado. Trinta e um eram do sexo feminino (68,89\%) e 14 masculino (31,11\%). A maioria dos casos diagnosticados eram invasivos (88,37\%) e o subtipo histológico predominante foi o lentiginoso acral (91,11\%). A região plantar foi a mais prevalente (64,44\%). A mediana do índice de Breslow foi de $3 \mathrm{~mm}$. Houve uma tendência a maior gravidade nos pacientes do sexo masculino.

CONCLUSÕES: Os melanomas de sítio acral são diagnosticados em fases mais avançadas o que acarreta pior prognóstico dos pacientes. Assume ainda maior importância em populações altamente miscigenadas e negras como a brasileira.

PALAVRAS-CHAVE: Melanoma/epidemiologia. Melanoma/patologia. Neoplasias cutâneas.

\section{REFERENCES}

1. Barbaric J, Sekerija M, Agius D, Coza D, Dimitrova N, Demetriou A, et al. Disparities in melanoma incidence and mortality in South-Eastern Europe: increasing incidence and divergent mortality patterns. Is progress around the corner? Eur J Cancer. 2016;55:47-55.

2. Sneyd MI, Cox B. A comparison of trends in melanoma mortality in New Zealand and Australia: the two countries with the highest melanoma incidence and mortality in the world. BMC Cancer. 2013;13:372.

3. Geller AC, Clapp RW, Sober AJ, Gonsalves L, Mueller L, Christiansen CL, et al. Melanoma epidemic: an analysis of six decades of data from the Connecticut Tumor Registry. J Clin Oncol. 2013;31(33):4172-8.

4. Moon KR, Choi YD, Kim JM, Jin S, Shin MH, Shim HJ, et al. Genetic alterations in primary acral melanoma and acral melanocytic nevus in Korea: common mutated genes show distinct cytomorphological features. J Invest Dermatol. 2018;138(4):933-45.

5. Shain AH, Bastian BC. From melanocytes to melanomas. Nat Rev Cancer. 2016;16(6):345-58

6. Luke J), Flaherty KT, Ribas A, Long GV. Targeted agents and immunotherapies: optimizing outcomes in melanoma. Nat Rev Clin Oncol. 2017;14(8):463-82

7. Moschos SJ, Pinnamaneni R. Targeted therapies in melanoma. Surg Oncol Clin N Am. 2015;24(2):347-58

8. lams WT, Sosman IA, Chandra S. Novel targeted therapies for metastatic melanoma. Cancer J. 2017;23(1):54-8.

9. Watts CG, Madronio C, Morton RL, Goumas C, Armstrong BK, Curtin A, et al. Clinical features associated with individuals at higher risk of melanoma: a population-based study. JAMA Dermatol. 2017;153(1):23-9.

10. Mahendraraj K, Sidhu K, Lau CS, McRoy G], Chamberlain RS, Smith FO. Malignant melanoma in African-Americans: a population-based clinical outcomes study involving 1106 African-American patients from the Surveillance, Epidemiology, and End Result (SEER) database (1988-2011). Medicine (Baltimore). 2017;96(15):e6258.

11. Gohara M. Skin cancer: an African perspective. Br J Dermatol. 2015;173(Suppl 2):17-21.

12. Oh Y, Choi S, Cho MY, Nam KA, Shin SJ, Chang JS, et al. Male sex and Breslow thickness are important risk factors for recurrence of localized melanoma in Korean populations. I Am Acad Dermatol. 2019. pii: S0190-9622(19)32773-2.
13. Nunes LF, Quintella Mendes GL, Koifman RI. Acral melanoma: a retrospective cohort from the Brazilian National Cancer Institute (INCA). Melanoma Res. 2018;28(5):458-64.

14. Yun SJ, Bastian BC, Duncan $L M$, Haneke E, Uhara H. Acral melanoma. In: Elder DE, Massi D, Scolyer RA, Willlemze R, eds. WHO classification of skin tumours. $4^{\text {th }}$ ed. Geneva: World Health Organization; 2018.

15. Häfliger EM, Ramelyte E, Mangana |, Kunz M, Kazakov DV, Dummer R, et al. Metastatic acral lentiginous melanoma in a tertiary referral center in Switzerland: a systematic analysis. Melanoma Res. 2018;28(5):442-50.

16. Bello DM, Chou JF, Panageas KS, Brady MS, Coit DG, Carvajal RD, et al. Prognosis of acral melanoma: a series of 281 patients. Ann Surg Oncol. 2013;20(11):3618-25.

17. Durbec F, Martin L, Derancourt C, Grange F. Melanoma of the hand and foot: epidemiological, prognostic and genetic features. A systematic review. $\mathrm{Br}$ | Dermatol. 2012;166(4):727-39.

18. Darmawan CC, Jo G, Montenegro SE, Kwak Y, Cheol L, Cho KH, et al. Early detection of acral melanoma: a review of clinical, dermoscopic, histopathology, and molecular characteristics. I Am Acad Dermatol. 2019;81(3):805-12.

19. Seui M, Takematsu H, Hosokawa M, Obata M, Tomita Y, Kato T, et al. Acral melanoma in Japan. J Invest Dermatol. 1983;80(1 Suppl):56s-60s.

20. Phan A, Touzet S, Dalle S, Ronger-Savié S, Balme B, Thomas L. Acral lentiginous melanoma: a clinicoprognostic study of 126 cases. Br J Dermatol. 2006;155(3):561-9.

21. Cherobin ACFP, Wainstein AJA, Colosimo EA, Goulart EMA, Bittencourt FV. Prognostic factors for metastasis in cutaneous melanoma. An Bras Dermatol. 2018;93(1):19-26.

22. Bartlett EK, Karakousis GC. Current staging and prognostic factors in melanoma. Surg Oncol Clin N Am. 2015;24(2):215-27.

23. Goydos JS, Shoen SL. Acral lentiginous melanoma. Cancer Treat Res. 2016;167:321-9.

24. Crocetti E, Fancelli L, Manneschi G, Caldarella A, Pimpinelli N, Chiarugi A, et al. Melanoma survival: sex does matter, but we do not know how. Eur j Cancer Prev. 2016;25(5):404-9.

25. Joosse A, De Vries E, van Eijck CH, Eggermont AM, Nijsten T, Coebergh JW. Reactive oxygen species and melanoma: an explanation for gender differences in survival? Pigment Cell Melanoma Res. 2010:23(3):352-64. 